\title{
LINGUISTIC ANALYSIS OF FLORA IMAGES IN THE RITUAL SUPERSTITIONS OF THE ENGLISH, RUSSIAN, AND MARI LANGUAGES
}

\author{
Ekaterina E. Fliginskikh* ${ }^{1 *}$ Galina N. Semenova ${ }^{2}$ \\ ${ }^{1}$ Senior Lecturer, Mari State University, RUSSIAN FEDERATION, katenasmile@mail.ru \\ ${ }^{2}$ Full Prof. Dr., I.N. Ulyanova Chuvash State University, RUSSIAN FEDERATION, \\ gncemenova@yandex.ru \\ ${ }^{*}$ Corresponding Author
}

\begin{abstract}
The objective of the article is to study superstitions with the names of plants connected with rites of pregnancy, birth, wedding, and death of three different languages: English, Russian, and Mari. The research shows that superstitions containing names of flora are distributed as following: English - 43 units, Russian 15 units, and Mari -28 units. Superstitions devoted to rites of pregnancy are presented by 12 units, birth -3 units, wedding -37 units, and death - 34 units. In general, 60 superstitions have positive meaning, and 26 negative meaning. The most popular plants are a rowan tree and a birch, both having an apotropaic meaning.
\end{abstract}

Keywords: superstitions, rites of passage, names of plants.

\section{INTRODUCTION}

The spiritual life of any nation is characterized by such a concept as animism which is belief in the existence of souls and spirits, belief in the animality of nature, and a fairly large part of this sphere is occupied by such objects of wildlife as plants.

Representatives of many peoples believe that a plant represents a spirit that can be good or evil. Through plants, these spirits were worshiped, asked for help or protection, and appeased.

Every nation has sacred trees that are worshiped and sacrificed. Thus, for example, among the Mari, sacred birch groves were widespread and still exist; all the main events occurring in human life are associated with them. People prayed in the birch groves, put the birch at the wedding table and planted it on the grave of the deceased. The bride made a sacrifice to the sacred birch of the family, birch branches were used to protect the wedding train (Toidybekova, 2007, p. 137-138).

The present article studies superstitions of the English, Russian, and Mari languages. These three languages are the languages of different language families, so they have different structures, features, and images. These languages present three different peoples with their own beliefs, traditions and rituals. The objective of the article is to compare these rituals represented in the superstitions.

Superstitions are the paroemiae which have a number of features, such as: 1 . They are verbalized units in the form of sentences; 2 . Their main function is a prognostic one; 3 . They appeared a lot of years ago and present the experience of the previous generations; 4 . They contain belief in something which cannot be explained with the help of logic and which is not proved by reasonable arguments (Fliginskikh, 2014 (1)).

Traditions, customs, and rituals always make a great part of everyday life of every folk. They cover all spheres: family, household, occupation, leisure time. But it is necessary to note that a lot of them are connected with rites of passage of a person from one state to another. They are mainly pregnancy, birth, wedding, death and funerals. In his book "The Rites of Passage" Arnold van Gennep presents a 
classification of rites where he distinguishes four categories: sympathetic and contagious rites, dynamistic and animistic rites, rites which act directly and indirectly, positive and negative rites. Another classification of rites presented by A. van Gennep is division of rites into rites of separation (preliminal rites), transition rites (luminal rites), and rites of incorporation (postliminal rites) (Gennep, 2004).

Rituals connected with these rites of passage determined the sequence of actions performed. The superstitions played an important role in these rituals having two main functions: preventive and prescriptive. On the one hand, they prohibited the performance of some actions preventing misfortunes. One the other hand, they give clear advice what to do to achieve what is desirable (Fliginskikh, 2014 (2)).

\section{MATERIALS AND METHODS}

The given linguistic study is based on the analysis of 43 superstitions in the English language, 15 - in Russian, and 28 - in Mari (total number is 86 ). The number of superstitions is limited by the fact that we have selected only the superstitions containing the names of plants and connected with the rites of passage. For this purpose we have used a method of continuous sampling in the following monolingual and multilingual dictionaries and books. We have considered different types of plants: trees, bushes, herbs, and flowers. We have used a number of books, dictionaries, encyclopaedias, collections, and ritual and tradition descriptions. The most used are presented below.

For the English superstitions: Multilanguage Dictionary of Superstitions and Omens (2013), The Encyclopedia of Superstitions by R. Webster (2008), books Superstitions: 1,013 of the World's Wackiest Myths, Fables \& Old Wives Tales by D.J. Murrel (2008), 8,414 Strange and Fascinating Superstitions by Cl. De Lys (2005), Black Cats and April Fools by H. Oliver (2006).

For the Russian superstitions: Multilanguage Dictionary of Superstitions and Omens (2013), books Everyday Life of a Noble Class of Pushkin Epoch by E.V. Lavrentyeva (2006), Black Cat with an Empty Bucket: Folk Omens and Superstitions by E.G. Lebedeva (2007) and Superstitions or prejudices? by Yu.V. Scsheglova (2007).

For the Mari superstitions: books Studies in Cheremis: the Supernatural by Th.A. Sebeok, Fr.J. Ingemann (1956) and Mari Mythology: Ethnographic Reference Book by L.S. Toidybekova (2007).

Frequency and statistical analysis was used to reveal the dominating plants, to count the superstitions devoted to different rites of passage in the three languages and to assess positive and negative percentage of superstitions in general.

Further we present a detailed investigation of a role of different flora objects in the rites of passage in three languages and cultures represented in the corresponding superstitions.

\section{RESULTS AND DISCUSSION}

\subsection{Linguistic Analysis of Lexical Units in the Superstitious Texts}

\subsubsection{Linguistic Analysis of Superstitions with the Names of Trees and Bushes}

Tree, garden, leaf, bush. In all three languages under study there are superstitions containing lexical units with a common meaning: tree, garden, leaf, bush (9 examples in three languages). Among them, one superstition in Russian with a negative connotation predicts the future for the baby: If the mother takes the baby off her breast at the time when the trees are blooming, it will turn gray early (RUS) (Lavrentyeva, 2006, p. 31). Three examples in the English and Mari languages are associated with predictions of love and wedding One the New year's Eve a girl lies down In the snow. If by morning a straw has fallen on the place where she lay, she will marry a rich man. If a leaf has fallen there, she will marry a poor man (MARI) (Sebeok, 1956, p. 219), If a man's hat goes against the branch of a tree, someone has fallen in love with him (ENG) (Murrel, 2008, p. 62). 5 examples in the Russian and Mari languages are associated with death: 1 with a positive connotation says that plants can have a soul: They never cut down a tree that grew on a grave. According to popular beliefs, a human soul could enter a tree (MARI) (Toidybekova, 2007, p. 200] and 4 predict death: If the tree dried up, they thought that the person who had planted it would soon leave this life (MARI) (Toidybekova, 2007, p. 61), If in the fall leaves stay green and unimpaired upon the trees, people will start dying (MARI) (Sebeok, 1956, p. 206). The analyzed examples show that any unusual natural phenomenon associated with plants was taken as a warning.

Rowan tree. Among the trees, rowan tree is most often mentioned (9 examples in three languages). As can be seen from the analyzed examples, rowan tree was one of the most common apotropaic, i.e. protective 
plants. Red berries, similar to blood, as well as the leaves and branches of the tree were used to protect the child from the evil eye, the bride from evil spirits and the deceased in the another world: To protect the bride from evil actions, rowan leaves and money were placed in the bride's bosom (RUS) (Zorin, 1990, p. 52), Rowan branches in the coffin helped to protect against evil spirits and dogs of the afterlife (MARI) (Sepeev, 2001, p. 140-141). Rowan is the most effective remedy against witches, fairies and any kind of evil eye or damage: Rowan tree was used to make cradles (ENG) (Braisher, 2002, p. 159). That is why all the example with the component rowan tree have positive meaning except one in Russian: Rowan cannot be cut down, especially near the house. If you cut it down, it means that you will soon die or there will be a death in the house (RUS) (Levedeva, 2007, p. 113). Since the rowan tree protected people, it was forbidden to harm it.

Birch. Another tree, which is referred to as a protective one in the Russian and Mari languages, is birch (6 superstitions in two languages). As it was mentioned earlier, the Mari pagans had sacred birch groves for prayers and sacred events. Each family had its own family birch tree and made sacrifices to it: On the wedding day, the bride made her first sacrifice to the family tree (birch) (MARI) (Toidybekova, 2007, p. 140). Birch possessed apotropaic power for both the living and the dead. During the wedding and funeral, people took into account its protective role: Birch brooms were placed in the coffin (RUS) (Zorin, Leshtaeva, 1990, p. 109], The birch was used to decorate the wedding train for the protective purpose (MARI) (Toidybekova, 2007, p. 139). Like rowan tree, birch should not be cut down, so as not to cause trouble for female relatives, as the birch was associated with a beautiful, flexible, slender girl (Glukhov, 2012, p. 57): To cut down a birch in a dream means wife or daughter will die (MARI) (Toidybekova, 2007, p. 139).

The rest of the names of trees and bushes are found in the superstitions of various languages associated with pregnancy, marriage and death / funeral.

Willow and linden could contribute to the cure of infertility (Russian and Mari examples): They advise all barren women to eat the buds of the consecrated willow, assuring that after this the woman will certainly start giving birth to children (RUS) (Shcheglova, 2007, p. 130), The barren women went after midnight to the sacred linden tree, climbed it nude, and then descended from it upside down (MARI) (Toidybekova, 2007, p. 191).

Alder acted as an apotropaic element during the wedding ceremony (Russian example): In order to protect newlyweds from bad eye, pieces of alder bark are put in their pockets (RUS) (Levedeva, 2007, p. 101). Alder bark is red in color which was considered protective (Fliginskikh, 2019).

Ash, poplar, yew and lilac in English examples give predictions about love and wedding. Ash and yew were used in fortune telling about the future spouse, and it was possible to make a spell on him or see him in a dream: An ash leaf with nine leaflets had to be searched for, and, when found, placed in the seekers bosom with the incantation: Here's an ash leaf with nine leaves on. Take it and press it to your heart and the first chap you'll meet be your sweetheart. If he's married let him pass by. If he's single, let him draw nigh (ENG) (Opie, 2005, p. 230), An unmarried woman could bring a branch of yew from the cemetery where she hadn't been before, put it under her pillow and see her betrothed in her dreams (ENG) (Webster, 2009, p. 274). With the help of lilac flowers, one could tell fortunes for a specific person: $A$ young single girl should eat lilac flowers with five petals - lucky lilac. If it was easy, a young man loves her as well; it was difficult, her sweetheart didn't feel to be in love with her (ENG) (Webster, 2009, p. 254). Poplar was a bad sign: Poplar trees brought bad luck to lovers (ENG) (Murrel, 2008, p. 71).

Willow, linden, oak and hawthorn predict death in the superstitions of three languages. It was bad to plant a tree, cut it down or bring it into the house: Whoever plants a willow, prepares a spade for himself (RUS) (Lebedeva, 2007, p. 19) (willow was used for making spade handles), If you cut down an oak, a man will die, if you cut down a linden, a woman will die (MARI) (Toidybekova, 2007, p. 61) (by analogy, an oak, as a stronger tree, meant a man, and a linden - a woman), Hawthorn in the house brought bad luck or death (ENG) (ENG) (Murrel, 2008, p. 71).

Linden, asp, yew and briar are found in the English and Mari positive or protective superstitions. Linden and briar helped the deceased in the afterlife to reach heaven and protect themselves from devils, evil spirits, dogs and snakes: Linden trees are planted at both ends of the grove; to these trees are fastened threads whereby the dead are believed to rise to heaven (MARI) (Toidybekova, 2007, p. 156), They put rosehip sticks into the coffin to protect the deceased from evil spirits and dogs in the afterlife (MARI) (Sepeev, 2001, p. 140-141). Asp and yew protected living people from the dead: An aspen stake was droven into the grave of an "unkind" person or a "walking" deceased (to close his way) (MARI) (Toidybekova, 2007, p. 265), The yew branches were put into the coffins for the deceased not to come and his/her phantom not to trace the alive (ENG) (Webster, 2009, p. 274). 
Proceedings of SOCIOINT 2021 8th International Conference on Education and Education of Social Sciences 14-15 June, 2021

\subsubsection{Linguistic Analysis of Superstitions with the Names of Herbs and Flowers}

Plant, flower. In the English and Russian languages there are superstitions containing lexical units with a common meaning: plant, flower (5 examples). All of them are associated with death: 1 with a positive connotation talking about grief: If someone dies in the family, the plants are decorated with a piece of black cloth for them to grieve together with the family (ENG) (Webster, 2008, p. 227), others predict death: If an indoor flower that has flowers in summer blooms in winter, it means death in the family (RUS) (Lebedeva, 2007, p. 107). English examples are based on the flower colour, as red and white are associated with blood and bandages and are often used for funerals: Red and white flowers mixed are also an omen of death (ENG) (Murrel, 2008, p. 31)

Hemp, ivy, peas, grain crops, sage, St. John's wort, dandelion, orchid, and mistletoe are found in the superstitions about pregnancy and children, but they have different meaning. Ficus, sage and St. John's wort could help infertile woman to become pregnant: $A$ barren woman shall plant a ficus in her bedroom and care for it as a child (RUS) (Lebedeva, 2007, p. 33-34). Different grain crops predicted pregnancy: If the front of the rye stack bulges, the woman will become pregnant (MARI) (Sebeok, 1956, p. 204). Hemp and mistletoe could predict infertility for both a man and a woman: $A$ man addicted to hemp could become barren (RUS) (Lebedeva, 2007, p. 111), If a girl gets married, and she has been never kissed under the mistletoe, she will be childless (ENG) (Webster, 2008, p. 193). Dandelion was used to guess the number of future children: The number of blowings predicts the number of children (ENG) (Webster, 2008, p. 191). Orchid, as it was thought, could influence the gender of a child: Some types of orchids have two humps. If men wanted a son, they ate a bigger hump; if they wanted a daughter, they ate a smaller one (ENG) (Webster, 2008, p. 196).

Hemp, ivy, peas, grain crops, St. John's wort, dandelion, mistletoe, flax, yarrow, clover, cabbage, daisy, agrostis, hydrangeas and orange blossoms are found in the superstitions about love and marriage. Most of the superstitions are connected with the fortunetelling about the betrothed ones. St. John's wort and clover helped to get know a future spouse irrespective of the gender: A two-leaf clover was placed in a shoe, and the next person of the opposite sex you met was your spouse-to-be-or at least had the same name as the future spouse (ENG) (Murrel, 2008, p. 53). Hemp, peas, grain crops, and clover revealed a future husband: A girl would go into a churchyard on Midsummer Eve (June 21st), or Halloween, Christmas Eve, St. Mark's Eve, Valentine's Day, and throw a handful of hemp seed behind her, then run away. If she was brave enough to turn her head and look behind her as she ran, she would see her future husband running after her with a scythe (ENG) (Murrel, 2008, p. 55), and ivy and yarrow showed a future wife: $A$ boy would traditionally gather ten ivy or sometimes yarrow leaves in silence, then throw away the tenth leaf. The nine remaining leaves were left outside until bedtime, when he brought them in and placed them in his right sock and under the pillow to see his future wife in his dreams (ENG) (Murrel, 2008, p. 57). Some of the fortunetelling could give characteristics to a future spouse. Girls could learn if they marry a rich or a poor person: On Christmas young people pull stalks from the stack. The one who pulls out a stalk on which there are many kernels will marry a rich person. The one who pulls out a stalk on which there are no kernels will marry a poor person (MARI) (Sebeok, 1956, p. 219). Boys could find out not only wife's wealth, but also her size: Young men could pull up plants, such as cabbage stalks, and tell by size whether their future wife would be tall or short. The amount of earth around the root symbolized the size of the wife's wealth (ENG) (Murrel, 2008, p. 63). Sometimes young people wanted to learn about the present love. Yarrow and daisy helped them in this case: While tickling your nose with the plant, you would recite the following: Yarroway, yarroway, bear a white blow / If my love loves me, my nose will bleed now. I If it did, you had your proof incontrovertible (ENG) (Murrel, 2008, p. 65).

Daisy and dandelion predicted the definite time until meeting the intended one or wedding: Girls used dandelions to learn the time of being unmarried: the number of blowings predicts the number of years (ENG) (Braisher, 2002, p. 163). Mistletoe and flax forecasted a wedding this year: After the uprooting of the flax a person puts a bit of flax on the table. As it is lit, the person says, "If I will get married this year, let the flame ruse up; if I will not get marries, let it burn low; let it not rise up" (MARI) (Sebeok, 1956, p. 218]. And vice versa, mistletoe could be a bad omen in one case: An unkissed girl under the mistletoe will not marry this year (ENG) (Webster, 2008, p. 193]. Agrostis was a sign of wedding with the beloved one: If a girl managed to kiss a beloved boy, she is not allowed to marry, under a stalk of agrostis, she will marry him (RUS) (Lavrentyeva, 2006, p. 405). But there were some bad signs as well. Ivy and hydrangeas were bad plants for girls as they predicted them the future of an old maid: Plant hydrangeas near your house and your daughters will never marry (ENG) (Murrel, 2008, p. 62).

Peas, mistletoe, henbane, laurel, and parsley are found in the superstitions about death. Most of superstitions under study predict death of a person: peas predict death to children; it is forbidden to cut 
mistletoe and sleep near the henbane; dry laurel is a bad sign; parsley shouldn't be planted in the garden. It's worth saying that all this is not coincidence. Laurel leaves were thought to be a symbol of eternal glory and special achievement, so dry laurel meant something bad: A dry laurel predicts death in the family (ENG) (Braisher, 2002, p. 157]. Parsley has been a symbol of oblivion and death since Ancient Greece: Replanting parsley means death in the family (ENG) (Webster, 2008, p. 206). Mistletoe is a symbol of love, friendship, and good luck that is why it was a bad sign to cut it: To cut a tree braided with mistletoe means to bring on death (ENG) (Braisher, 2002, p. 166]. Henbane belongs to a family of highly poisonous and notorious plants: Do not sleep near henbane or you will never wake up (RUS) (Pankeev, 2008, p. 111).

\subsection{Frequency Analysis of Lexical Units in the Superstitious Texts}

\subsubsection{Frequency Analysis of Superstitions with the Names of Trees and Bushes}

We have studied 14 English, 9 Russian, and 21 Mari superstitions with the names of trees and bushes. From Tables 1-3 we can see the following. English superstitions mostly express positive meaning about wedding and are connected with fortunetelling about future husband or wife, but there are no examples devoted to pregnancy. Russian and Mari superstitions are mostly connected with death, but they are positive as they give advice for protection.

Table 1. Distribution of examples in the English language

\begin{tabular}{|c|c|c|c|c|c|c|c|c|}
\hline \multirow[t]{2}{*}{ English } & \multicolumn{2}{|c|}{ Pregnancy } & \multicolumn{2}{|c|}{ Birth } & \multicolumn{2}{|c|}{ Wedding } & \multicolumn{2}{|c|}{ Death } \\
\hline & + & - & + & - & + & - & + & - \\
\hline tree & & & & & 1 & & & \\
\hline bramble & & & & & 1 & & & \\
\hline rowan & & & 1 & & & & 1 & \\
\hline ash & & & & & 4 & & & \\
\hline yew & & & & & 1 & & 2 & \\
\hline poplar & & & & & & 1 & & \\
\hline lilac & & & & & 1 & & & \\
\hline hawthorn & & & & & & & & 1 \\
\hline
\end{tabular}

Table 2. Distribution of examples in the Russian language

\begin{tabular}{|l|c|c|c|c|c|c|c|c|}
\hline Russian & \multicolumn{2}{|c|}{ Pregnancy } & \multicolumn{2}{c|}{ Birth } & \multicolumn{2}{c|}{ Wedding } & \multicolumn{2}{c|}{ Death } \\
\hline & + & - & + & - & + & - & + & - \\
\hline tree, garden & & & & 1 & & & & 1 \\
\hline rowan & & & & & 1 & & 1 & 1 \\
\hline birch & & & & & & & 1 & \\
\hline willow & 1 & & & & & & & 1 \\
\hline alder & & & & & 1 & & & \\
\hline
\end{tabular}


Table 3. Distribution of examples in the Mari language

\begin{tabular}{|c|c|c|c|c|c|c|c|c|}
\hline \multirow[t]{2}{*}{ Mari } & \multicolumn{2}{|c|}{ Pregnancy } & \multicolumn{2}{|c|}{ Birth } & \multicolumn{2}{|c|}{ Wedding } & \multicolumn{2}{|c|}{ Death } \\
\hline & + & - & + & - & + & - & + & - \\
\hline tree & & & & & & & 1 & 3 \\
\hline leaf & & & & & & 1 & & \\
\hline rowan & & & 1 & & 1 & & 2 & \\
\hline birch & & & & & 2 & & 2 & 1 \\
\hline linden & 1 & & & & & & 1 & 1 \\
\hline asp & & & & & & & 1 & \\
\hline oak & & & & & & & & 1 \\
\hline briar & & & & & & & 2 & \\
\hline
\end{tabular}

\subsubsection{Frequency Analysis of Superstitions with the Names of Herbs and Flowers}

We have studied 29 English, 6 Russian, and 7 Mari superstitions with the names of herbs and flowers. Tables 4-6 we show the following. English superstitions mostly express positive meaning about wedding and are connected with fortunetelling about future husband or wife, but there are no examples devoted to birth. Russian and Mari superstitions are distributed, but Russian examples are mostly negative and Mari examples are mostly positive.

Table 4. Distribution of examples in the English language

\begin{tabular}{|c|c|c|c|c|c|c|c|c|}
\hline \multirow[t]{2}{*}{ English } & \multicolumn{2}{|c|}{ Pregnancy } & \multicolumn{2}{|c|}{ Birth } & \multicolumn{2}{|c|}{ Wedding } & \multicolumn{2}{|c|}{ Death } \\
\hline & + & - & + & - & + & - & + & - \\
\hline plant & & & & & & & 1 & \\
\hline flower & & & & & & & & 2 \\
\hline hemp & & & & & 1 & & & \\
\hline ivy & & & & & & & & \\
\hline peas & & & & & 1 & & & \\
\hline sage & 1 & & & & & & & \\
\hline St. John's wort & 1 & & & & 1 & & & \\
\hline dandelion & 1 & & & & 1 & & & \\
\hline orchid & 1 & & & & & & & \\
\hline mistletoe & & 1 & & & 1 & 1 & & 1 \\
\hline yarrow & & & & & 2 & & & \\
\hline
\end{tabular}


Proceedings of SOCIOINT 2021 8th International Conference on Education and Education of Social Sciences 14-15 June, 2021

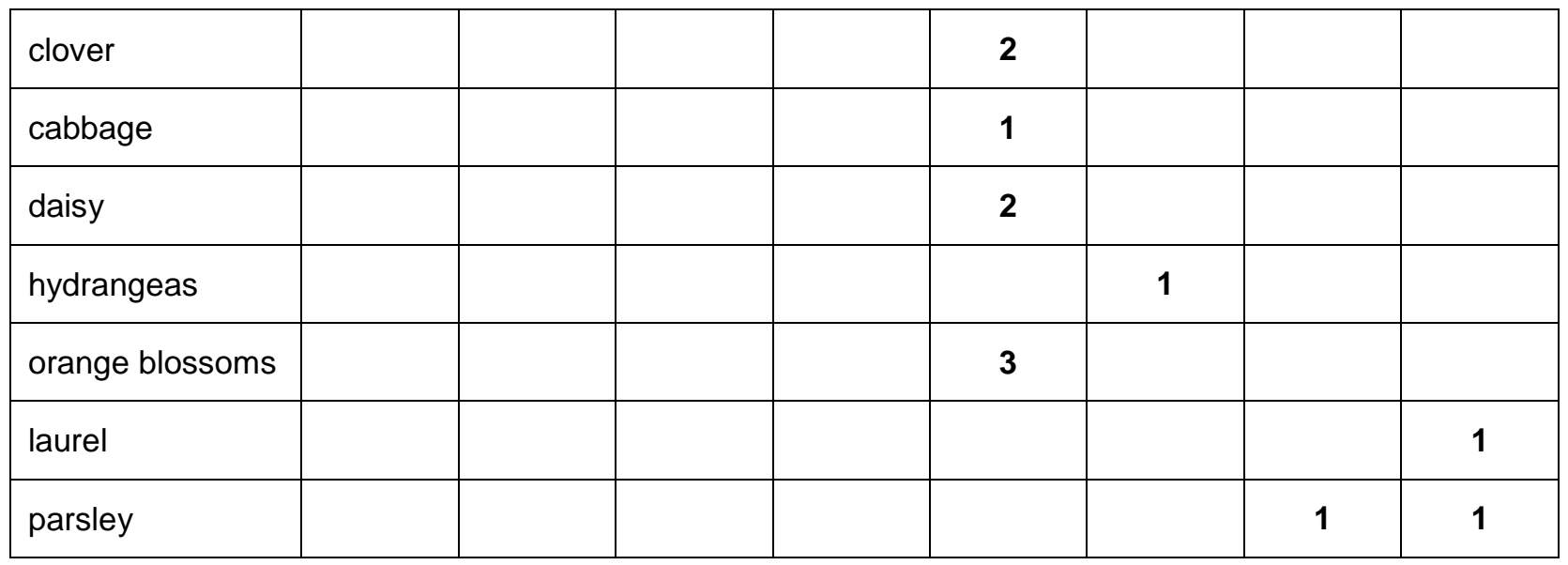

Table 5. Distribution of examples in the Russian language

\begin{tabular}{|l|c|c|c|c|c|c|c|c|}
\hline \multirow{2}{*}{ Russian } & \multicolumn{2}{|c|}{ Pregnancy } & \multicolumn{2}{c|}{ Birth } & \multicolumn{2}{c|}{ Wedding } & \multicolumn{2}{c|}{ Death } \\
\hline & + & - & + & - & + & - & + & - \\
\hline flower & & & & & & & & 1 \\
\hline hemp & & 1 & & & & & & \\
\hline ivy & & & & & & 1 & & \\
\hline ficus & 1 & & & & & & & \\
\hline agrostis & & & & & 1 & & & \\
\hline henbane & & & & & & & & 1 \\
\hline
\end{tabular}

Table 6. Distribution of examples in the Mari language

\begin{tabular}{|l|c|c|c|c|c|c|c|c|}
\hline Mari & \multicolumn{2}{|c|}{ Pregnancy } & \multicolumn{2}{c|}{ Birth } & \multicolumn{2}{c|}{ Wedding } & \multicolumn{2}{c|}{ Death } \\
\hline & + & - & + & - & + & - & + & - \\
\hline peas & & & & & & & & 1 \\
\hline grain crops & 3 & & & & 2 & & & \\
\hline flax & & & & & 1 & & & \\
\hline
\end{tabular}

\subsubsection{Comparative Analysis of Superstitions according to the Rites of Passage}

The results of the research presented in table 7 show that the superstitions containing names of flora objects are most popular in the English language -43 units. Russian and Mari examples are much more limited (15 and 28 units correspondingly). Superstitions devoted to rites of pregnancy are presented by 12 units, birth 3 units, wedding -37 units, and death -34 units in the three languages. They are distributed among the languages in the following number. Superstitions about pregnancy: English -5 units, Russian -3 units, Mari - 4 units; superstitions about birth: English - 1 unit, Russian - 1 unit, Mari - 1 unit; superstitions about wedding: English -26 units, Russian -4 units, Mari -7 units; superstitions about death: English -11 units, Russian -7 units, Mari -16 units.

In general 60 examined superstitions in three languages have positive meaning, and 26 - negative which is mostly connected with a lot of fortunetelling examples. Positive meaning is greatly predominant in the 
English and Mari languages. There are 33 positive vs 10 negative superstitions in English, and 20 vs 8 in in Mari. In Russian the distribution is almost equal: 7 vs 8 . There are more positive examples of superstitions connected with pregnancy and wedding in all three languages. Correspondingly, there are more negative examples connected with death in English and Russian.

The most popular flora object is a rowan tree (9 examples in the three languages connected with birth, wedding, and death). The image of a rowan is mostly positive. Such frequency of this component in the superstitions is explained by its wide distribution on the territory of peoples under study, and especially by its apotropaic character which was very important for every event.

Table 7. Comparative frequency analysis in three languages

\begin{tabular}{|l|c|c|c|c|c|c|c|}
\hline & \multicolumn{3}{|c|}{ English } & \multicolumn{3}{c|}{ Russian } & \multicolumn{2}{c|}{ Mari } \\
\hline & + & - & + & - & + & - & \\
\hline pregnancy & 4 & 1 & 2 & 1 & 4 & - & 12 \\
\hline birth & 1 & - & - & 1 & 1 & - & 3 \\
\hline wedding & 23 & 3 & 3 & 1 & 6 & 1 & 37 \\
\hline death & 5 & 6 & 2 & 5 & 9 & 7 & 34 \\
\hline & 33 & 10 & 7 & 8 & 20 & 8 & \\
\hline & \multicolumn{2}{|c|}{43} & & 15 & & 28 & \\
\hline
\end{tabular}

\subsection{Symbolic Analysis of Lexical Units in the Superstitious Texts}

The symbolic analysis presents meaning of the flora objects in the superstitions in the three languages. These meaning are presented in tables 8-9.

\subsubsection{Symbolic Analysis of Superstitions with the Names of Trees and Bushes}

Table 8. Meaning of the images in three languages

\begin{tabular}{|l|l|l|l|}
\hline \multicolumn{1}{|c|}{ English } & \multicolumn{1}{c|}{ Russian } & \multicolumn{1}{c|}{ Mari } \\
\hline willow & - & $\begin{array}{l}\text { curing infertility } \\
\text { death }\end{array}$ & - \\
\hline linden & - & - & $\begin{array}{l}\text { curing infertility } \\
\text { protection } \\
\text { death }\end{array}$ \\
\hline trees blooming & love & $\begin{array}{l}\text { child's future } \\
\text { death }\end{array}$ & - \\
\hline bramble & love & - & - \\
\hline poplar & no luck in love & - & - \\
\hline lilac & love / no love & - & - \\
\hline ash & betrothed & - & - \\
\hline
\end{tabular}


Proceedings of SOCIOINT 2021 8th International Conference on Education and Education of Social Sciences 14-15 June, 2021

\begin{tabular}{|c|c|c|c|}
\hline yew & $\begin{array}{l}\text { betrothed } \\
\text { protection }\end{array}$ & - & - \\
\hline leaf & death & - & wedding \\
\hline rowan & protection & $\begin{array}{l}\text { protection } \\
\text { death }\end{array}$ & protection \\
\hline birch & - & protection & $\begin{array}{l}\text { protection } \\
\text { death }\end{array}$ \\
\hline alder & - & protection & - \\
\hline asp & - & - & protection \\
\hline briar & - & - & protection \\
\hline tree & death & - & $\begin{array}{l}\text { soul } \\
\text { death }\end{array}$ \\
\hline oak & - & - & death \\
\hline hawthorn & no luck / death & - & - \\
\hline
\end{tabular}

3.3.2 Symbolic Analysis of Superstitions with the Names of Herbs and Flowers

Table 9. Meaning of the images in three languages

\begin{tabular}{|l|l|l|l|}
\hline & \multicolumn{1}{|c|}{ English } & \multicolumn{1}{c|}{ Russian } & \multicolumn{1}{c|}{ Mari } \\
\hline sage & pregnancy & - & - \\
\hline St. John's wort & $\begin{array}{l}\text { pregnancy } \\
\text { betrothed }\end{array}$ & - & - \\
\hline ficus & - & pregnancy & pregnancy \\
\hline grain crops & - & - & betrothed \\
\hline orange blossoms & purity and fertility & - & - \\
\hline mistletoe & $\begin{array}{l}\text { infertility } \\
\text { chance of wedding } \\
\text { death }\end{array}$ & - & - \\
\hline hemp & betrothed & infertility & - \\
\hline dandelion & $\begin{array}{l}\text { number of children } \\
\text { time before wedding }\end{array}$ & - & - \\
\hline orchid & child's gender & - & - \\
\hline
\end{tabular}


Proceedings of SOCIOINT 2021 8th International Conference on Education and Education of Social Sciences 14-15 June, 2021

\begin{tabular}{|c|c|c|c|}
\hline daisy & $\begin{array}{l}\text { love } \\
\text { time before meeting }\end{array}$ & - & - \\
\hline ivy & love / betrothed & keeping men off & - \\
\hline yarrow & love / betrothed & - & - \\
\hline peas & betrothed & - & death \\
\hline clover & betrothed & - & - \\
\hline cabbage & betrothed & - & - \\
\hline flax & - & chance of wedding & - \\
\hline agrostis & - & wedding & - \\
\hline hydrangeas & no wedding & - & - \\
\hline plant & grief & - & - \\
\hline flower & death & death & - \\
\hline henbane & - & death & - \\
\hline laurel & death & - & - \\
\hline parsley & $\begin{array}{l}\text { death } \\
\text { death prevention }\end{array}$ & - & - \\
\hline
\end{tabular}

\section{CONCLUSION}

A linguistic analysis presented in the research gives a detailed description of all flora images existing In the superstitions of the English, Russian, and Mari languages.

A Frequency analysis let us make a conclusion that superstitions containing names of different kinds of plants as their components are more spread in the English language. The most popular rite of passage is wedding. Moreover, there is the greatest number of positive examples about wedding in the English language, which shows the popularity of fortunetelling superstitions.

A symbolic analysis shows us that there are superstitions about fertility, infertility and its curing; some of them are devoted to children. However, it should be mentioned that the most of superstitions are connected with love, wedding, death prediction and protection. Moreover, rowan tree is the only component that exist in the superstitions of all three languages and has the same meaning - protection of alive and dead people.

So we can say that existence of flora objects as components of the superstitions can help to show the relations of the folks to these plants, their understanding of nature and help researchers to reveal and interpret their way of life, beliefs and rituals.

\section{REFERENCE LIST}

Braisher, S. M. (2002). Omens and Beliefs.

Fliginskikh, E. E. (2014). Ritual Superstitions in the Culture of Russian People, Vestnik of the Mari State University, No. 3 (15).

Fliginskikh, E. E. (2014). Towards the Definition of a Term "Superstition". Vestnik Chuvashskogo 
Universiteta, Humanities, No. 1.

Fliginskikh, E. E. (2014). Towards the Definition of a Term "Superstition". Vestnik Chuvashskogo Universiteta, Humanities, No. 1.

Fliginskikh, E. E., Semenova, G. N., Yakovleva, S. L., Mitrofanova, T. A., Andrianova, E. (2019). Adjectives in the Superstitions of the English, Russian, and Mari Languages. INTCESS 2019 - 6th international conference on education and social sciences.

Gennep, A., van (2004). The Rites of Passage.

Glukhov, V. A., Glukhova, N. N. (2012). The Systems of Symbols in the Songs of Finno-Ugric Peoples of the Urals-Volga Region.

Lavrentyeva, E. V. (2006). Everyday Life of a Noble Class of Pushkin Epoch.

Lebedeva, E. G. (2007). Black Cat with an Empty Bucket: Folk Omens and Superstitions.

Lys, Cl., de (2005). 8,414 Strange and Fascinating Superstitions.

Multilanguage Dictionary of Superstitions and Omens (2013).

Murrel, D. J. (2008). Superstitions: 1,013 of the World's Wackiest Myths, Fables \& Old Wives Tales.

Oliver, H. (2006). Black Cats and April Fools.

Opie, I., Tatem, M. (2005). Oxford Dictionary of Superstitions.

Pankeev, I. A. (2008). Secrets of Russian superstitions Панкеева.

Scsheglova, Yu.V. (2007). Superstitions or prejudices?

Sebeok, Th. A., Ingemann, Fr. J. (1956). Studies in Cheremis: the Supernatural.

Этнография марийского народа: Учебное пособие для старших классов /Сост. Г.А. Сепеев. - ЙошкарОла: Марийское книжное издательство, 2001. - 184 с.; ил.

Toidybekova, L. S. (2007). Mari Mythology: Ethnographic Reference Book.

Webster, R. (2008). The Encyclopedia of Superstitions.

Zorin, N. V. (1990). Ritual functions of clothes in the Russian wedding ritual of the Middle Volga Region. Family traditions of the Middle Volga Region folks.

Zorin, N. V., Leshtaeva, N. V. (1990). Funeral ritual of the Russian people living in the Kazan Volga Region (end of XIX - beginning of XX century). Family traditions of the Middle Volga Region folks. 